\title{
Evolutionary change in the germination niche between related species within Neoporteria clade (Cactaceae) is idiosyncratic to habitat type
}

\section{El cambio evolutivo en el nicho de germinación de dos especies relacionadas dentro del clado Neoporteria (Cactaceae) es idiosincrático al tipo de hábitat}

\author{
Pablo C. Guerrero ${ }^{1,2 *}$, Daniela Mardones ${ }^{1}$, Nataly Viveros ${ }^{1,2}$, Francisco T. Peña-Gómez ${ }^{2,3}$ \& \\ RAMIRO O. BUSTAMANTE 2,3 \\ ${ }^{1}$ Departamento de Botánica, Facultad de Ciencias Naturales y Oceanográficas, Universidad de Concepción, Casilla 160-C, \\ Chile. \\ ${ }^{2}$ Instituto de Ecología y Biodiversidad, Universidad de Chile, Las Palmeras 3425, Casilla 653, Ñuñoa, Chile. \\ ${ }^{3}$ Departamento de Ciencias Ecológicas, Facultad de Ciencias, Universidad de Chile, Casilla 653, Santiago, Chile. \\ *pabloguerrero@udec.cl
}

\begin{abstract}
An appropriate germination response to environmental conditions is the first requirement for the establishment of a plant in a determined geographic area; therefore changes in the germination niche may be critical in configuring the current pattern of species distributions. Furthermore, the spread of many Neotropical groups to higher latitudes are constrained by the combination of cold and humid conditions. This raises the question whether evolutionary trends in germination niche are essential for the mechanism that allows the colonization of edge habitats characterized by humid and cold conditions. Here, we evaluated the variation of seed germination probabilities of two species of cacti (Neoporteria clade), closely related but endemic to habitats with different temperature and water availability conditions. The germination niche and differences in germination performance of Eriosyce subgibbosa and E. villosa were evaluated, using common garden experiments and varying temperature and soil water potential $(\Psi)$ conditions. Seeds of E. subgibbosa showed overall higher germination probabilities compared to $E$. villosa. Interestingly, most of the detected differences on seed germination performance are related with a higher ability of E. subgibbosa seeds to germinate under conditions with more water availability and under colder conditions compared to E. villosa seed germination. This study highlights one of the critical features that could be involved in the mechanism that leads to the expansion of the Neoporteria clade to more mesic habitats. Particularly the adaptation of the germination niche of E. subgibbosa may allow an expansion from an arid habitat that characterized basal species of the group (plesiomorphic state) to more humid and cold habitats.
\end{abstract}

KEYwords: Endemism, ontogenetic niche, biogeography, Mediterranean biome, Chile.

\section{RESUMEN}

Una respuesta apropiada a las condiciones ambientales es el primer requisito para el establecimiento de una planta en un área geográfica, por lo tanto cambios en el nicho de germinación podrían ser críticos en configurar el actual patrón de distribución de especies. Además, la propagación de muchos grupos de origen neotropical hacia altas latitudes está limitada por la combinación de condiciones frías y alta humedad. Esto lleva a preguntarse si las tendencias evolutivas en el nicho de la germinación son esenciales en el mecanismo que permite la colonización del borde del hábitat caracterizado por ser frío y húmedo. Por ello, evaluamos la variación en las probabilidades de germinación de dos especies de cactáceas (clado Neoporteria), cercanamente relacionadas pero endémicas a hábitats con diferentes condiciones de temperatura y disponibilidad de agua. Usando experimentos de jardín común se varió la temperatura y el potencial osmótico del sustrato $(\Psi)$, se caracterizó el nicho evaluando las diferencias germinativas en Eriosyce subgibbosa y E. villosa. Las semillas de E. subgibbosa mostraron en general mayor germinación que las semillas de E. villosa. Interesantemente, la mayoría de las diferencias detectadas en la germinación de semillas están relacionadas con la mayor habilidad de las semillas de E. subgibbosa a germinar bajo condiciones de mayor disponibilidad hídrica y menores temperaturas comparado con la germinación de E. villosa. Este estudio llama la atención sobre uno de los aspectos críticos que podrían estar involucrados con el mecanismo que podría llevar la expansión del clado Neoporteria a hábitats más mésicos. Particularmente la adaptación del nicho de germinación de E. subgibbosa podría permitir la expansión en la distribución de un habitat árido que caracteriza a las especies basales del grupo como E. villosa (carácter plesiomórfico) hacia hábitats más húmedos y fríos.

Palabras clave: Endemismo, nicho ontogenético, biogeografía, bioma Mediterráneo, Chile. 


\section{INTRODUCTION}

The ecological niche is a pivotal concept in ecology, evolution and biogeography, allowing to understand the processes related to survival, reproduction and dispersal of species (Holt 2009, Soberón \& Nakamura 2009, Guerrero et al. 2013). Part of the importance of this concept relies on the ability of organisms to conserve (or not) their ecological niches (Wiens et al. 2010). Within the various factors that define the species niche, those related with early stages of life cycles largely determine the population dynamics of species (Grubb 1977, Poorter 2007). These stages are also critical because they determine the fitness of individuals, and thus are target of natural selection allowing adaptive changes (Post 2003). For example, changes associated with requirements for seed germination are regarded as important evolutionary forces for species living under different climatic conditions (Cruden 1974).

The germination of seeds is one of the earliest ecological processes that determine the occurrence of a species in a plant community. To recruit a new individual into a population, a set of specific environmental conditions is required for seed germination in the place where seeds are dispersed (Donohue et al. 2010, Braz et al. 2014). Seed germination is a process that depends on the microenvironment experimented by seeds (Baskin \& Baskin 2014). In this sense, environmental variables that configure the micro-habitat where occurs seed germination is known as the 'germination niche' (Harper et al. 1965, Donohue et al. 2005). Species with a broader germination niche may germinate in a wider range of environmental conditions than species with a narrow niche breadth (Luna \& Moreno 2010, Braz et al. 2014). An appropriate seed germination response to the microenvironment experimented by seeds is the first requirement for the establishment of a plant in a particular habitat (Donohue et al. 2005). Therefore, changes in germination niche among species of a clade may be an adaptive response to different environmental conditions (Cruden 1974).

Despite the strong relationship between germination niche and the ecological divergence of species, the role of seed germination in contributing to species ecological breadth and geographic distribution is still a matter of debate (Rodrigues-Marques et al. 2014). Also, the evolutionary trends of germination niche among relatives are far from been understood. Only recently has there been an interest in addressing the conservatism of regeneration niche traits related to seed germination (Walck \& Hidayati 2004, Burns $\&$ Strauss 2011). For instance, when there is a niche change between relatives it is considered labile, whereas when this feature does not change between related species is considered that the niche is conserved (Losos et al. 2003). In general, neotropical lineages which have marked niche conservatism cannot colonize cold and rainy zones (Wiens
\& Donoghue 2004). For example, the cactus lineage (family level) is distributed from Canada to Patagonia, covering a large set of climates (Anderson 2001), but it is absent in the wettest and coldest areas of the continent. It seems that the combination of low temperatures and excessive rainfall, severely constraints the distribution of cacti, thus avoiding the colonization of southwestern South America (Guerrero et al. 2011a). The relationship between germination niche and distribution of cacti is fairly unknown, but there is an important amount of information showing that seed germination of most cacti decreases at low temperature $(<$ $20^{\circ} \mathrm{C}$ ), severe aridity (Guerrero 2011), and absence of light (Rojas-Aréchiga \& Vásquez-Yañes 2000, Guerrero et al. 2011b).

The genus of cacti Eriosyce sensu lato (Kattermann 1994) from Notocacteae tribe, occupies arid and sem-arid biomes. Interestingly, Eriosyce subgibbosa (Haw.) Katt. can live in conditions of higher humidity and lower temperatures compared to any other species of Notocacteae. This has led us to characterize and compare germination niche of two species of clade Neoporteria, currently within the Eriosyce sensu lato group. Eriosyce villosa (Monv.) Katt. was choose since is a basal species within the Neoporteria clade that occupies arid habitats in the coastal desert of Chile (Guerrero et al. 2011c). In addition, we studied the germination niche of E. subgibbosa a derived species in relation to E. villosa. The objective of this study is to characterize and compare variation pattern of the germination niche between two related Eriosyce species of the Neoporteria clade, and test whether these differences are in accordance with the environmental characteristics of their habitats.

\section{METHODS}

Eriosyce subgibbosa and E. villosa belong to the same clade of cacti, but occupy different habitats. Eriosyce villosa occupies a fraction of the Desert-Coastal Mediterranean bioclimate (Fig. 1), and E. subgibbosa mainly occupies the coastal zone of oceanic-pluviseasonal mediterranean bioclimate (Luebert \& Pliscoff 2006). These two bioclimates differ, among other factors, on temperature and rainfall conditions (Fig. 1). These differences account for major abiotic habitat conditions where the germination of the two studied species occur in nature, in contrast, soil properties even that may have some differences they tend to be similar since these species are specialized to regenerate in the crack of coastal rocks (Guerrero unpublished data).

Seeds of these two species were obtained from natural populations in central Chile from mature fruits of fifteen individuals per species, between October and December 2009. In the case of E. villosa seeds were collected at the locality of Huasco $\left(28.467^{\circ} \mathrm{S} ; 71.219^{\circ} \mathrm{W}\right)$, while $E$. subgibbosa seeds were collected at Punta de Lobos in 
Pichilemu $\left(34.426^{\circ} \mathrm{S} ; 72.043^{\circ} \mathrm{W}\right)$. Seeds from both species were pooled and maintained during five (E. villosa) and three (E. subgibbosa) months in dry conditions until the start of the experiments. To characterize the germination niche a factorial experiment was conducted using two treatments: species (E. subgibbosa and E. villosa), and two treatments each with several levels of mean daily temperature $\left(6.5^{\circ} \mathrm{C}\right.$, $13^{\circ} \mathrm{C}, 18.5^{\circ} \mathrm{C}$ and $24.5^{\circ} \mathrm{C}$ ) and soil water potential ( $\Psi:-0.25$, $-0.5,-1$ and $-1.5 \mathrm{Mpa}$ ). Temperature varied following day/ night cycles as photoperiod $(12 / 12 \mathrm{~h}): 6.5^{\circ} \mathrm{C}$ (day: $4^{\circ} \mathrm{C}$ / night: $\left.9^{\circ} \mathrm{C}\right), 13^{\circ} \mathrm{C}\left(11^{\circ} / 16^{\circ} \mathrm{C}\right), 18.5^{\circ} \mathrm{C}\left(16^{\circ} / 21^{\circ} \mathrm{C}\right)$ and $24.5^{\circ} \mathrm{C}\left(22^{\circ} / 27^{\circ} \mathrm{C}\right)$. The criteria to choose thermoperiods in the experimental design were (i) include a wide range of temperature conditions, (ii) use realistic values of maximum and minimum temperature variation that seeds may experience in their habitats (using Huasco and Pichilemu as references, Fig. 1) within a year, and (iii) maintain the same amplitude of variation between the highest and the lowest temperature. The effect of soil water potential was evaluated using a range of concentrations of mannitol diluted in deionized water $(0,0.1,0.2,0.4$ y $0.6 \mathrm{~mol} / \mathrm{L})$, to generate osmotic potentials in the substrate of $0,-0.25$, $-0.5,-1$ and -1.5 Mpa. Higher concentrations of mannitol generate more negative osmotic pressures and therefore water is less available for seeds (Cárdenas \& Villegas 2002). We did not include -1.5 Mpa water potential into statistical analyses because we did no obtain germination at all. Each combination of treatment and level was replicated in five and ten seeds per replicate were sown in petri dishes. We sowed ten seeds in closed petri dishes, on $2 \mathrm{~g}$ of vermiculite and deposited in a germination chamber that have fluorescent lights, control temperature with $\pm 0.5^{\circ} \mathrm{C}$ of precision and with polyurethane temperature isolation. All treatments were watered with deionized water at the start of the experiment and then once a week (maintaining mannitol concentrations of each treatment). The effects of solutes upon water potentials $(\Psi)$ was calculated based on the expression: $\Psi=-\mathrm{RTC}$, where $\mathrm{R}$ is the ideal gas constant,
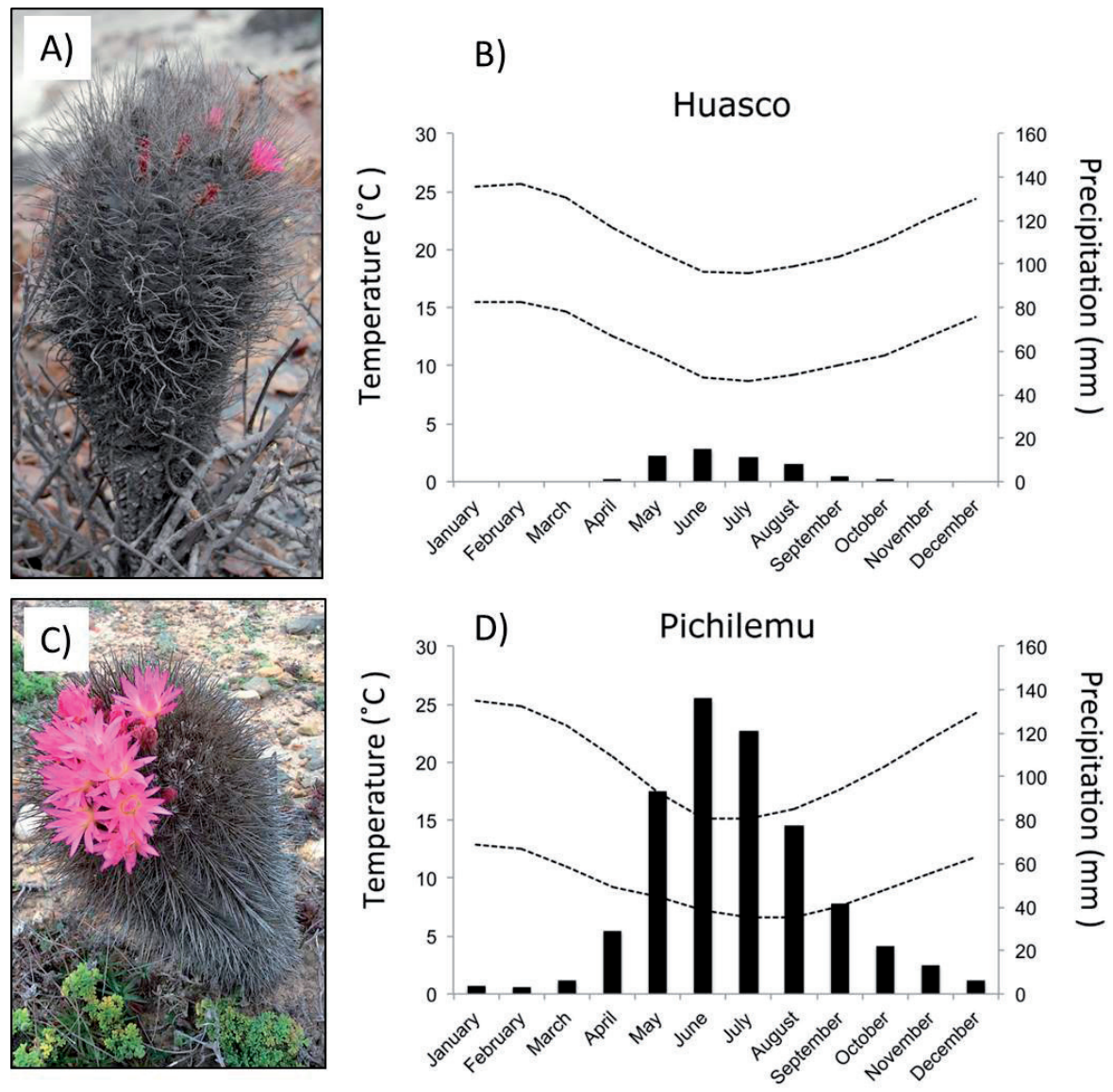

Figure 1. Species included in the study and averaged bioclimatic variables (records from the 1950-2000 period) of Huasco and Pichilemu (climatic data from Hijmans et al. 2005). A, Eriosyce villosa; B, monthly temperature and precipitation at Huasco $\left(28.467^{\circ} \mathrm{S} ; 7^{2} .219^{\circ} \mathrm{W}\right)$; C, E. subgibbosa; D, monthly temperature and precipitation at Pichilemu $\left(34.426^{\circ} \mathrm{S} ; 72.043^{\circ} \mathrm{W}\right)$.

Figura 1. Especies incluidas en el estudio y variables bioclimáticas promediadas (registros del periodo 1950-2000) de Huasco y Pichilemu (datos climáticos de Hijmans et al. 2005). A, Eriosyce villosa; B, temperatura mensual y precipitación en $\mathrm{Huasco}\left(28.467^{\circ} \mathrm{S} ; 7^{2} .219^{\circ} \mathrm{O}\right)$; C, E. subgibbosa; D, temperatura mensual y precipitación en Pichilemu $\left(34.426^{\circ} \mathrm{S} ; 72.043^{\circ} \mathrm{O}\right)$. 
$\mathrm{T}$ the absolute temperature, and Cs the osmolarity of the mannitol solution (Swagel et al. 1997). Germination was recorded until no new germinated seeds were observed during three consecutive weeks, taking two months in total. Seeds were considered viable if at the end of the experiment they maintained their hardness and the embryos were white and turgescent. Using this criterion we observed that all seeds were viable.

Significant differences between the germination of both species at different temperatures and soil water potential were tested, performing a three way ANOVA in STATISTICA 7 (StatSoft 2004), where the response variable was the probability of germination and independent variables were temperature, soil water potential and species. The probabilities of germination were transformed to arcsine to meet the normality data assumptions (Zar 1999).

\section{RESULTS}

Seed germination of both species varied greatly among the different levels of temperature and osmotic water potential (Figure 2). The maximum germination of seeds was detected at the highest temperatures $\left(16^{\circ} / 21^{\circ} \mathrm{C}\right.$ and $\left.22^{\circ} / 27^{\circ} \mathrm{C}\right)$ and osmotic water potentials $(0,-0.25,-0.5)$. In contrast, at osmotic water potentials less than -1, a germination of less than $20 \%$ was obtained under all temperatures. Seeds of $E$ subgibbosa showed an overall higher germination probabilities than E. villosa $(\mathrm{F}=12.44, \mathrm{p}<0.0001$, Figure $2)$. Also, seed germination varied significantly between soil water potentials $(\mathrm{F}=162.20, \mathrm{p}<0.0001)$ and among the three temperature conditions $(\mathrm{F}=73.67, \mathrm{p}<0.0001)$. Furthermore, differences were significant for the interaction between species and soil water potential $(\mathrm{F}=4.51, \mathrm{p}=$ $4-9^{\circ} \mathrm{C}$
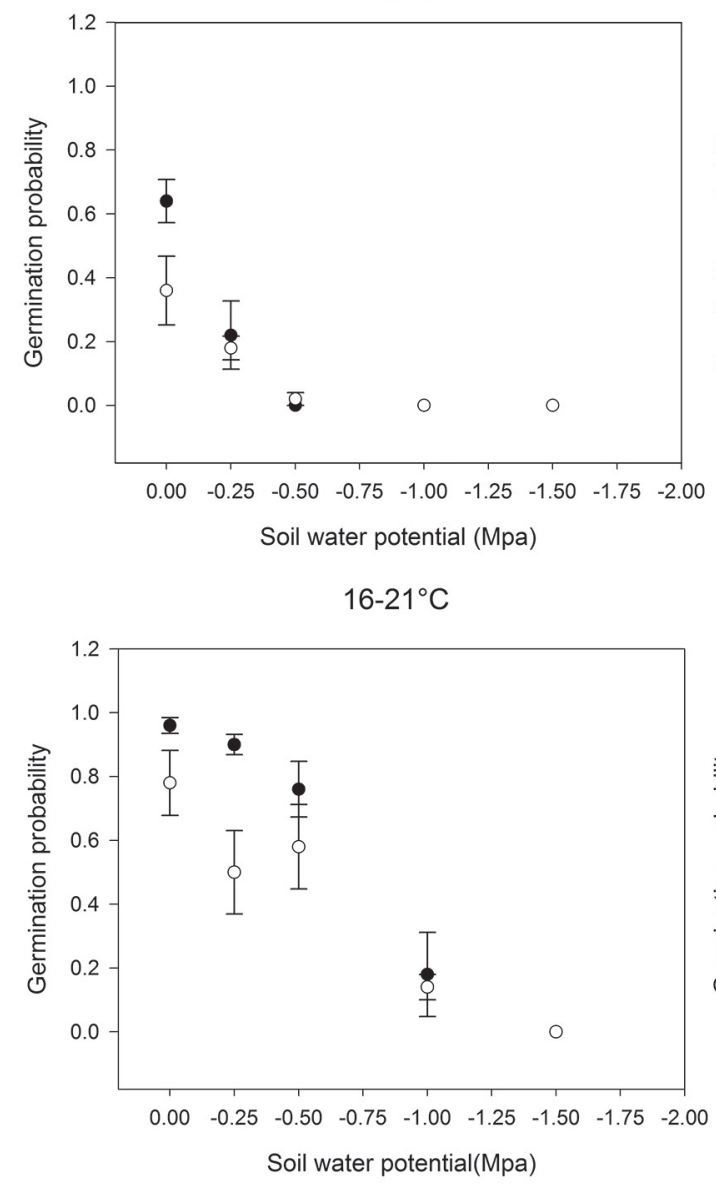

$11-16^{\circ} \mathrm{C}$

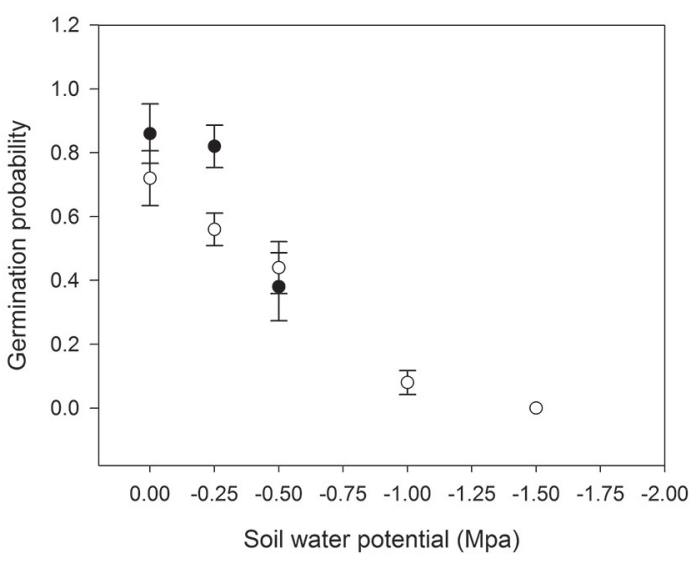

$22-27^{\circ} \mathrm{C}$

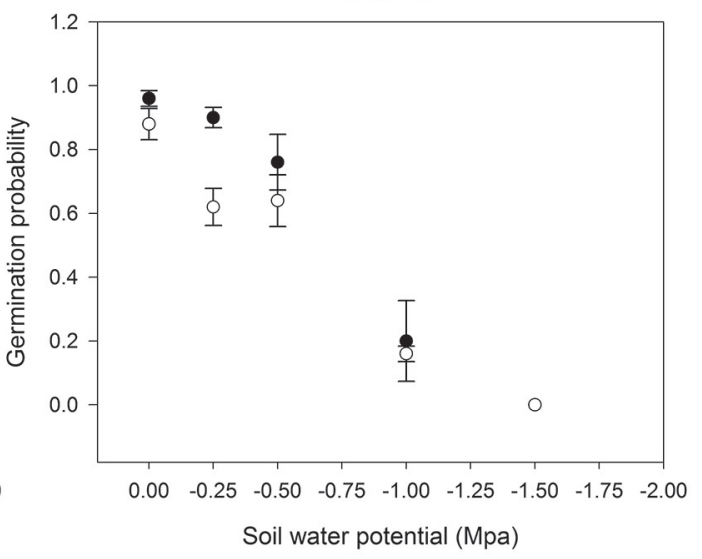

FIGURE 2. Probability of germination of Eriosyce subgibbosa (black circles) and E. villosa (white circles) under different temperature and soil water potential (mean and S.E.).

FIgURA 2. Probabilidad de germinación de Eriosyce subgibbosa (círculos negros) y E. villosa (círculos blancos) bajo temperatura y potencial osmótico del suelo diferentes (media y E.S). 
$0.0013)$ and among soil water potential and temperature (F $=8.03, \mathrm{p}<0.0001)$. The interaction between species and temperature $(\mathrm{F}=1.74, \mathrm{p}=0.15)$ and the triple interaction between species, temperature and soil water potential were not significantly different $(\mathrm{F}=1.09, \mathrm{p}=0.36)$.

\section{DISCUSSION}

The results indicate that the two studied species of the clade Neoporteria (E. subgibbosa and E. villosa) varied their germination response to different conditions of temperature and soil water potential. In particular, this difference is given because E. subgibbosa can germinate more than E. villosa especially under higher water availability (higher soil water potential) (Fig. 2). The higher germination of E. subgibbosa under conditions of high water availability compared to $E$. villosa, suggests the existence of an adaptive response of $E$. subgibbosa to the idiosyncratic weather conditions where it is distributed. This ability allows E. subgibbosa to take advantage of the rainfall in its habitat because precipitation is particularly abundant during cold months (Fig. 1). A fast response to rain may be advantageous because allows seedlings develop early and grow to a size that enables them to withstand the subsequent dry period (Fenner \& Thompson 2005). In the germination of both species a decrease in germination was observed in conditions of less soil water potential, suggesting that aridity could be a severe limitation for both species, thus constraining the expansion of species distributions into hyperarid areas of the core of the Atacama Desert. This decay in seed germination under dry conditions could promote fragmentation of the distribution areas of Eriosyce species. Since dry phases of pluvial cycles (sensu Latorre et al. 2006) could diminish the availability of suitable areas (safe sites) for germination and regeneration (Guerrero et al. 2011c). Similar patterns of seed germination responses to soil water potential have been shown in other desert plants as in shrubs (i.e. Cercidium praecox (Ruiz \& Pav.) Harms and Prosopis laevigata (Humb. \& Bonpl. ex Willd.) M.C. Johnst. and columnar succulents (Neobuxbaumia tetetzo (F.A.C.Weber ex K.Schum.) Backeb. and Pachycereus hollianus (F.A.C.Weber) Buxb.) (Flores \& Briones 2001).

No significant effect of the triple interaction between species, temperature and soil water potential was detected, this suggest differential responses of species seeds to factors that may be annulling their effects. For example, seed germination of species was similar in relation to temperature, since both species germinated more at higher temperatures. However, a closer look of data revealed that $>50 \%$ of seeds of E. subgibbosa were able to germinate at low temperature (day: $4^{\circ} \mathrm{C} /$ night: $9^{\circ} \mathrm{C}$ ), ) and high water availability. In contrast to the seeds of $E$. villosa which showed very low germination $(<50 \%)$ at low temperatures (i.e. day: $4^{\circ} \mathrm{C} /$ night: $9^{\circ} \mathrm{C}$ ) at any water potential. Similar effects have been reported for cacti in Brazil (Zamith et al. 2013). This result suggests that suitable conditions (presence of rainfall) for germination of $E$. subgibbosa seeds are achieved almost throughout the year (Fig. 1). In contrast, seeds of E. villosa could germinate only during the autumn-winter months, since historically significant levels of rainfall are recorded only in four months during a year (Figure 1). Consequently, the results of germination niche are consistent with the climatic conditions where these species are distributed. These trends in germination niche suggest an evolutionary history of the Neoporteria clade linked to climatic gradient of central Chile (Guerrero et al. 2011c).

\section{ACKNOWLEDGEMENTS}

This study was supported by PFB-23 and ICM P00502, currently PCG research activities are supported by FONDECYT \#1160583. Also we want to acknowledge two anonymous reviewers that enhanced the quality of this manuscript.

\section{REFERENCES}

Anderson, E.F. 2001.The cactus family. Portland, Timber Press. $776 \mathrm{pp}$

BASKIN, C.C. \& J.M. BASKIN. 2014. Seeds: ecology, biogeography, and evolution of dormancy and germination. Academic Press, California. 1586 pp.

Braz, M.I.G., R.D.C.Q. Portela, L.H.M. Cosme, V.G.C. Marques \& E.A. De Mattos. 2014. Germination niche breadth differs in two co-occurring palms of the Atlantic Rainforest. Natureza \& Conservação 12(2): 124-128.

Burns, J.H. \& S.Y. Strauss. 2011. More closely related species are more ecologically similar in an experimental test. Proceedings of the National Academy of Sciences USA 108(13): 5302-5307.

Cardenas, A. \& A. Villegas. 2002. Osmotic potential of culture medium with different compounds for the in vitro propagation. Revista Fitotecnia Mexicana 25: 213-217.

Cruden, R.W. 1974. The adaptive nature of seed germination in Nemophila menziesii Aggr. Ecology 55(6): 1295-1305.

Donohue, K., L. Dorn, C. Griffith, E. Kim, A. Aguilera, C.R. Polisetty \& J. Schmitt. 2005. The evolutionary ecology of seed germination of Arabidopsis thaliana: variable natural selection on germination timing. Evolution 59(4): 758-770.

Donohue, K., R. Rubio De Casas, L. Burghardt, K. Kovach \& C.G. Willis. 2010. Germination, postgermination adaptation, and species ecological ranges. Annual Review of Ecology, Evolution and Systematics 41: 293-319.

Fenner, M. \& K. Thompson. 2005. The Ecology of Seeds. Cambridge University Press, Cambridge. 250 pp.

Flores, J. \& O. Briones. 2001. Plant life-form and germination in a Mexican inter-tropical desert: effects of soil water potential and temperature. Journal of Arid Environments 
47(4): 485-497.

GrubB, P.J. 1977. The maintenance of species-richness in plant communities: the importance of the regeneration niche. Biological Reviews 52: 107-145.

Guerrero, P.C. 2011. Biogeografía y evolución de la familia Cactaceae: divergencia del grupo Eriosyce subgen. Neoporteria bajo gradientes climáticos en Chile mediterráneo. Tesis. Doctor en Ciencias, Facultad de Ciencias, Universidad de Chile, Santiago, Chile. 152 pp.

Guerrero, P.C., P. Durán \& H.E. Walter. 2011a. Latitudinal and altitudinal patterns of the endemic cacti from the Atacama desert to Mediterranean Chile. Journal of Arid Environments 75(11): 991-997.

Guerrero, P.C., L. Alves-Burgos, F.T. Peña-Gómez \& R.O. Bustamante. 2011b. Positive photoblastic response of seed germination in Eriosyce subgen. Neoporteria (Britton \& Rose) Helmut Walter (Cactaceae). Gayana Botánica 68(1): 110-113.

Guerrero, P C., M.T.K. Arroyo, R.O. Bustamante, T. Hagemann \& H.E. Walter. 2011c. Phylogenetics and predictive distribution modeling provide insights into infrageneric relationships and the evolution of the Eriosyce subgen. Neoporteria (Cactaceae). Plant Systematics and Evolution 297: 113-128.

Guerrero, P.C., M. Rosas, M.T.K. Arroyo \& J.J. Wiens. 2013. Evolutionary lag times and recent origin of the biota of an ancient desert (Atacama-Sechura). Proceedings of the National Academy of Sciences USA 110(28): 1146911474.

Harper, J.L., J.T. Williams \& G.R. SAgar. 1965. The behaviour of seeds in soil: I. The heterogeneity of soil surfaces and its role in determining the establishment of plants from seed. Journal of Ecology 53(2): 273-286.

Hijmans, R.J., S.E. Cameron, L. Parra, P.G. Jones \& A. Jarvis. 2005. Very high resolution interpolated climate surfaces for global land areas. International Journal of Climatology 25(15): 1965-1978.

Holt, R.D. 2009. Bringing the Hutchinsonian niche into the 21st century: ecological and evolutionary perspectives. Proceedings of the National Academy of Sciences USA 106: 19659-19665.

Kattermann, F. 1994. Eriosyce (Cactaceae) the genus revised and amplified. Succulent Plant Research 1: 1-176.

Latorre, C., J.L. Betancourt \& M.T.K. Arroyo. 2006. Late Quaternary vegetation and climate history of a perennial river canyon in the Rio Salado basin $\left(22^{\circ} \mathrm{S}\right)$ of northern Chile. Quaternary Research 65(3): 450-466.

Losos, J.B., M. Leal, R.E. Glor, K. De Queiroz, P.E. Hertz, L. Rodríguez Schettino, A.C. Lara, T.R. Jackman \& A. LARSON. 2003. Niche lability in the evolution of a Caribbean lizard community. Nature 424: 542-545.

LuEBERT, F. \& P. PlisCofF. 2006. Sinopsis bioclimática y vegetacional de Chile. Santiago, Chile, Editorial Universitaria. 316 pp.

LunA, B. \& J.M. Moreno. 2010. Range-size, local abundance and germination niche-breadth in Mediterranean plants of two life-forms. Plant Ecology 210(1): 85-95.

Martins, L.S.T., T.S. Pereira, A.S.D.R. Carvalho, C.F. Barros, \& A.C.S. De Andrade. 2012. Seed germination of Pilosocereus arrabidae (Cactaceae) from a semiarid region of south-east Brazil. Plant Species Biology 27(3): 191-200.

Poorter, L. 2007. Are species adapted to their regeneration niche, adult niche, or both? American Naturalist 169(4): 433-442.

Post, D.M. 2003. Individual variation in the timing of ontogenetic niche shifts in largemouth bass. Ecology 84(5): 1298-1310.

Rodrigues-Marques, A., A.P.F. Atman, F.A.O. Silveira \& J.R. De Lemos-Filho. 2014. Are seed germination and ecological breadth associated? Testing the regeneration niche hypothesis with bromeliads in a heterogeneous Neotropical montane vegetation. Plant Ecology 215(5): 517-529.

Rojas-Aréchiga, M. \& C. VÁsqueZ-Yañes. 2000. Cactus seed germination: a review. Journal of Arid Environments 44(1): 85-104.

Soberón, J. \& M. NaKamura. 2009. Niches and distributional areas: concepts, methods, and assumptions. Proceedings of the National Academy of Sciences USA 106(Suppl 2): 19644-19650.

StATSOFt, Inc. 2004. STATISTICA (data analysis software system), version 7. www.statsoft.com.

Swagel, E.N., A. Van H. Bernhard \& G.S. Ellmore. 1997. Substrate water potential constraints on germination of the strangler fig Ficus aurea (Moraceae). American Journal of Botany 84: 716-722.

WalcK, J.L. \& S.N. HidayaTi. 2004. Germination ecophysiology of the western North American species Osmorhiza depauperata (Apiaceae): implications of preadaptation and phylogenetic niche conservatism in seed dormancy evolution. Seed Science Research 14(4): 387-394.

Wiens, J.J. \& M.J. Donoghue. 2004. Historical biogeography, ecology, and species richness. Trends in Ecology and Evolution 19(12): 639-644.

Wiens, J.J., D.D. Ackerly, A.P. Allen, B.L. Anacker, L.B. Buckley, H.V. Cornell, E.I. Damschen, D.T. Jonathan, J.A. Grytnes, S.P. Harrison, B.A. Hawkins, R.D. Holt, C.M. McCain \& P.R. Stephens. 2010. Niche conservatism as an emerging principle in ecology and conservation biology. Ecology Letters 13(10): 1310-1324.

ZAmith, L., D. CRUZ \& B. Richers. 2013. The effect of temperature on the germination of Melocactus violaceus Pfeiff. (Cactaceae), a threatened species in restinga sandy coastal plain of Brazil. Anais da Academia Brasileira de Ciências 85(2): 615-622.

ZAR, J.H. 1999. Biostatistical Analysis. New Jersey, Prentice-Hall, Inc. $663 \mathrm{pp}$.

Recibido: 10.03 .16

Aceptado: 09.08.16 